\title{
Interest Rate Variability: Its Link to the Variability of Monetary Growth and Economic Performance
}

\author{
John A. Tatom
}

2

SINCE, 1979 , interest rate volatility has been unusually high, subjecting investors to increased risk on their retums. When investment is riskier, risk-averse investors demand a higher rate of return as an incentive to continue investing. Evans (1984) shows that the rise in the volatility of interest rates in 1980-81 had a significant negative effect on output in the United States, which he attributes to the policy of monetary stock control implemented in 1979.' Other investigators have noted that money growth volatility increased substantially after 1979 and have attributed many of the unusual features of economic performance since 1980 to this increase.?

The purpose of this paper is to examine both the link between money growth and interest rate variability and the effects of interest rate variability on U.S. economic performance. This examination is conducted using a model in which money growth is exogenous, and past interest rate and money growth variability are taken to be exogenous for the determination of current economic performance.

John A. Tatom is a research officer at the Federal Reserve Bank of St. Louis. Thomas A. Gregory provided research assistance.

'See Evans (1984). The 1979 policy change is discussed by Lang (1980) and Gilbert and Trebing (1981). Subsequent policy alterations are discussed by Thornton (1983) and Wallich (1984). For an extensive set of criticisms of central bank policy aimed at money stock control, especially the policies of the Federal Reserve from 1979-82, see the citations in Batten and Stone (1983), p. 5.

aSee Friedman (1983), Bomhoff (1983), Tatom (1983), Bodie, Kane and McDonald (1983), Mascaro and Meltzer (1984) and Belongia (1984).
The article first examines the recent experience with unusually high variability of both money growth and interest rates. This section clarifies why variability matters, and describes the type of interest rate variability that, in theory, affects economic decision-making. Other measures of interest rate variability that were examined in the course of this research are also indicated. A specific measure of variability that has the desired theoretical property is then shown to be positively influenced by the level of money growth variability. This relationship is demonstrated using the experience of the past 60 years.

Next, the article turns to the link between interest rate variability and economic performance. The theoretical channels of influence of both money and interest rate variability on economic performance are explained. These hypotheses are tested using a small reduced-form model of the economy. These tests also delineate whether it is anticipated or unanticipated interest rate volatility that accounts for the observed effects. Finally, empirical estimates of the economic effects of interest rate variability over the past four years are presented.

The empirical results point to several difficulties in implementing tests of the interest rate variability hypothesis. Only a few measures of interest rate variability strongly support the hypotheses tested. While these few have desirable theoretical and statistical properties, other standard measures of variability provide mixed results, at best, in the tests of their effects on economic performance. This study focuses on only one measure of interest rate variability. This measure has significant effects on the levels of GNP. prices and real output during the periods examined; it is also 
Chart I

\section{Short-run and Trend Money Growth}

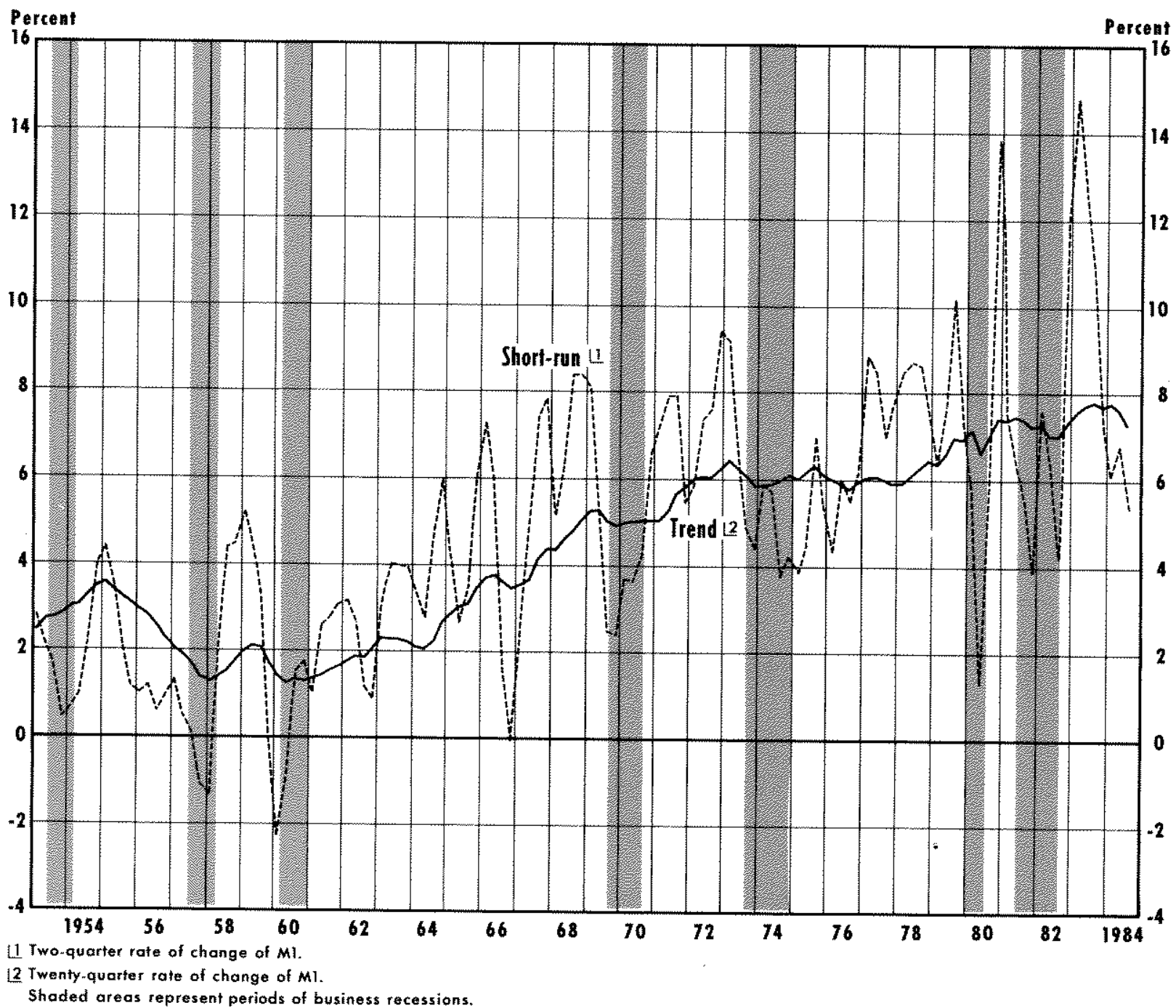

shown to be influenced by the variability of money growth."

\section{THE RECENT EXPERIENCE IN PERSPECTIVE}

The growth rate of the money stock (M1) has been more volatile since 1979 than in the previous 27 years.

The link between money growth variability and these other measures of interest rate variability was not examined because these other measures do not appear to systematically affect economic performance.
Chart 1 shows the annual rate of growth for two-quarter periods and the longer-term trend rate of expansion (five years) since 1953. Economic theory and empirical evidence indicate that sharp swings in the two-quarter growth rate of the money stock temporarily affect the growth rate of output and employment. The shaded areas in the chart, which indicate periods of business recession, are associated with relatively sharp slowings in short-run money growth relative to the trend growth rate.

Chart 1 also shows that the gyrations of money growth about trend have been unusually wide since 
Chan 2

\section{Standard Deviations of Quarterly MI Growth}

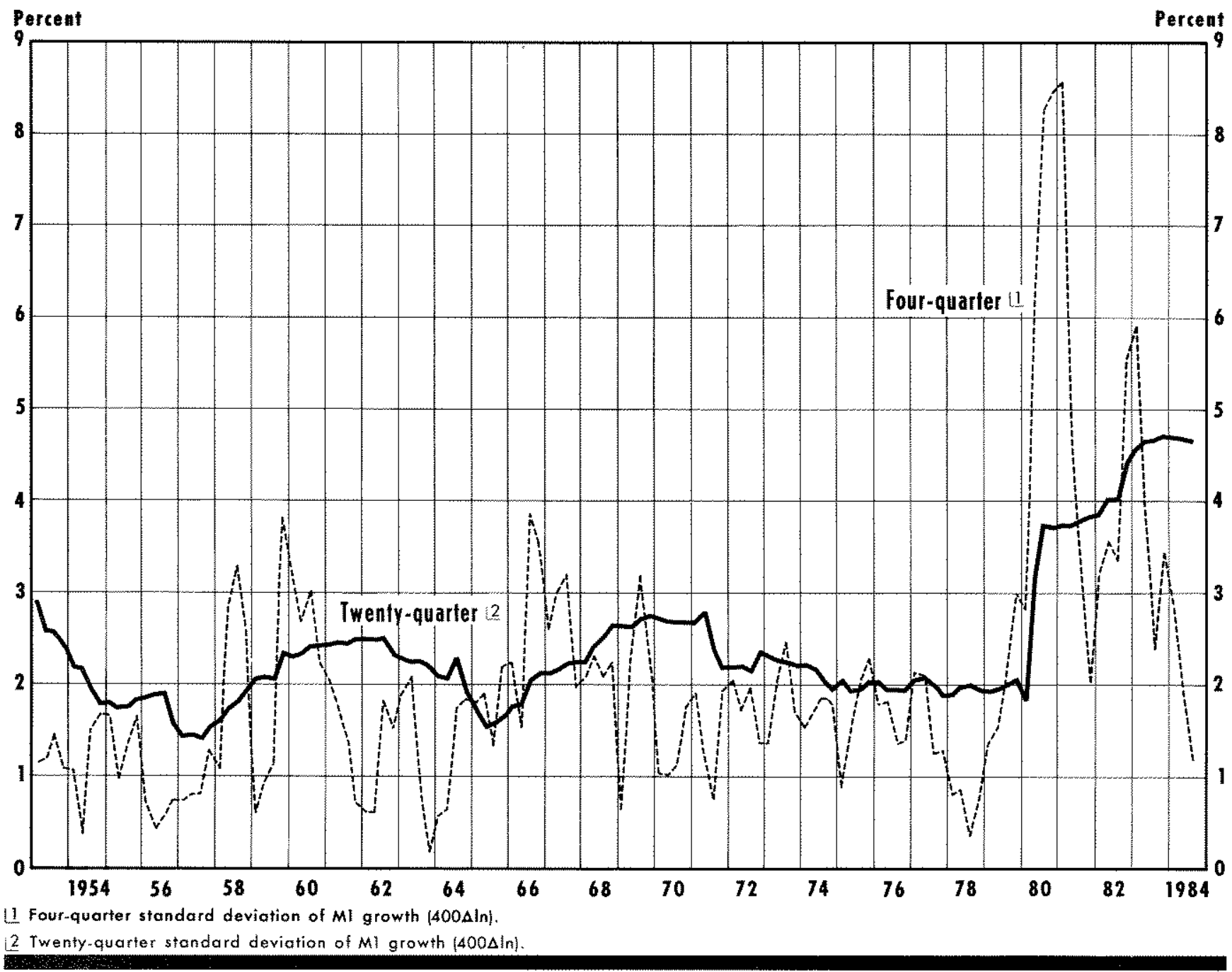

1979. Statistical measures of money growth variability strongly support this visual evidence. Chart 2 shows the standard deviations for the growth rate of the quarterly money stock measured over the most recent four and 20 quarters since 1953. Both measures show relatively high levels of volatility since $1979 .^{*}$

4There are several reasons for increased variability of money growth since 1979. For example, Weintraub (1980), Tatom (1982). Hein (1982) and Board of Governors of the Federal Reserve System (1981) emphasize the effect of the credit control program on the currency ratio and, hence, on the link between reserves and mone* tary aggregates in mid-1980. This factor contributed to the rise in the variability of money growth in 1980. Others have emphasized problems associated with financial innovations, especially late in 1982 and early in 1983, that led to the temporary abandonment of M1 targeting in October 1982 .

\section{The Variability of Interest Rates}

The variability of expected returns affects decisions because it influences the variability of wealth the present value of expected income streams . For example, the present value of real income expressed as a perpetuity is inversely proportional to the expected yield. That is, wealth $(W)$ is the flow of income per year (V) discounted by the rate of interest paid on a perpetuity (i), $W=\mathrm{Y} / \mathrm{i}$.

Wealth holders are concerned with the likelihood of percentage variations in interest rates rather than absolute percentage point changes. The wealth effect of a 100 basis-point change in the expected interest rate is greater when the expected interest rate is 3 percent 
than when it is $\mathbf{1 5}$ percent. In the former case, wealth can change by about one-third; in the latter case, wealth changes by about 6 percent. If risk is measured relative to the expected return, the variability of returns should be measured relative to the mean return. The logarithm of the interest rate provides such a mean-adjusted measure. The variability of the logaFithm of wealth is directly related to the variability of the logarithm of the expected yield." Risk is measured here using the yield on Aa bonds, since it is the longterm yield that is most important for capital accumulation and has the greatest impact on wealth.

The expected volatility of rates of return is an important determinant of investment decisions. It is not possible, however, to directly measure this risk." If assessments of this risk are reflected in the actual variability of yields, then the variability of interest rates in the recent past can be used as an indicator of risk. Even then, the length of the relevant past is essentially an empirical issue.

Chart 3 shows the standard deviation of the logarithm of the quarterly Aaa bond yield, measured for the four and 20 quarters ending in each quarter shown, respectively, for the period from 1924 to 1983. These measures summarize the riskiness of yields during the respective past period. Both measures indicate a shafp jump to record levels in the variability of interest rates after 1979 . In 1984, the 20-quarter measure declined sharply from its peak in early 1982 , but it remained near previous peaks achieved in the mid1930s, early 1960 s and early 1970 s.

\section{Other Measures of Interest Rate Variability}

There are a variety of other ways to measure the variability of interest rates. For example, Evans (1984) uses the standard deviation of monthly interest rate changes over a one-year period. The list of standard deviation measures examined for this article includes,

sGiven expected income, $(\bar{Y})$, wealth is $W=Y / /$ and the lagarithm (in) of wealth is in $\bar{Y}-$ in $i$. Thus, in $W$ is inversely related to in $i$ and the variance of $\ln W$ is proportional to the variance of $\ln i$. Note also that the variance of ( $\mathrm{n}$ i) is independent of the level of the interest rate since $\operatorname{Var}[\mathrm{ln}(\mathrm{k} i)]=\operatorname{Var}(\mathrm{ln} \mathrm{i})$, where $\mathrm{k}$ is a scalar muitiple.

ift would be most useful to measure the variability of the expected after-tax real rate of return and that of the expected rate of inflation separately. Makin and Tanzi (1983) argue that an increase in both factors account for the increased volatility of interest rates in 198082. Since both have qualitatively the same effect on investment, production and money demand incentives, the distinction is ignored here. besides the two measures in chart 3 , the standard deviations of: the level of the quarterly interest rate, the change in the quarterly interest rate and the change in the logarithm of the quarterly interest rate. To test the effects of variability on economic performance, each standard deviation measure, as well as the logarthm of each measure, was used. Two other measures were examined as well: the average absolute change in the level of the quarterly interest pate and the coefficient of variation of the quarterly interest rate. All measures were computed for four ${ }^{-}, 12-$ and 20-quarter petiods

The best tesults ljudged by robustness across periods of time and relative explanatory power for economic performance were found using the 20-quarter standard deviation of the logarithm of the interest rate; this measure is called VR here. Virtually the same results are obtained using the 20 -quarter coefficient of variation, which is simply an altemative way of adjusting the variability of the interest tate for different mean levels over time. As emphasized above, it is such mean-adjusted measures of variability that, in principle, should matter. Other measures generally do not have significant economic effects; in those cases where significant economic effects are observed, relationships usually are either not robust or are statistically inferior in terms of explanatory power. These exceptions are noted below.

Interest rate variability measures inherently depend on past interest rates. Fon example, a rise or fall in interest rates from one level that has persisted for a considerable time to another that will persist for a long time to come, will lead to a transitory rise in the variability of interest rates during the transition from the former to the latter and for some period subsequently. The Aaa bond yield has broadly followed a pattern of three level shifts from 1955 to 1983 ; it rose from about 3 percent during $1950-55$ to near 4.5 percent during 1960-65, then rose to about 8 percent from 1970 to early 1977, and finally surged upward to an average of 13 percent in 1980-83.

The three major spikes for the 20-quarter measure in chart 3 are consistent with such level shifts in interest rates. There are two ways to interpret this rise in variability. One way would suggest that the rise is purely arithmetic with no economic consequences for perceived investment risk. The alternative view is that the rise in interest rate variability associated with such level shifts in interest rates mirrors the increased risk perceived from such unforeseen changes. Moreover, this risk, like the variability measure, is reduced slowly over time. This article assumes that the second inter- 
Chart 3

\section{Standard Deviations of the Logarithm of the Quarterly Average Aaa Bond Yield}

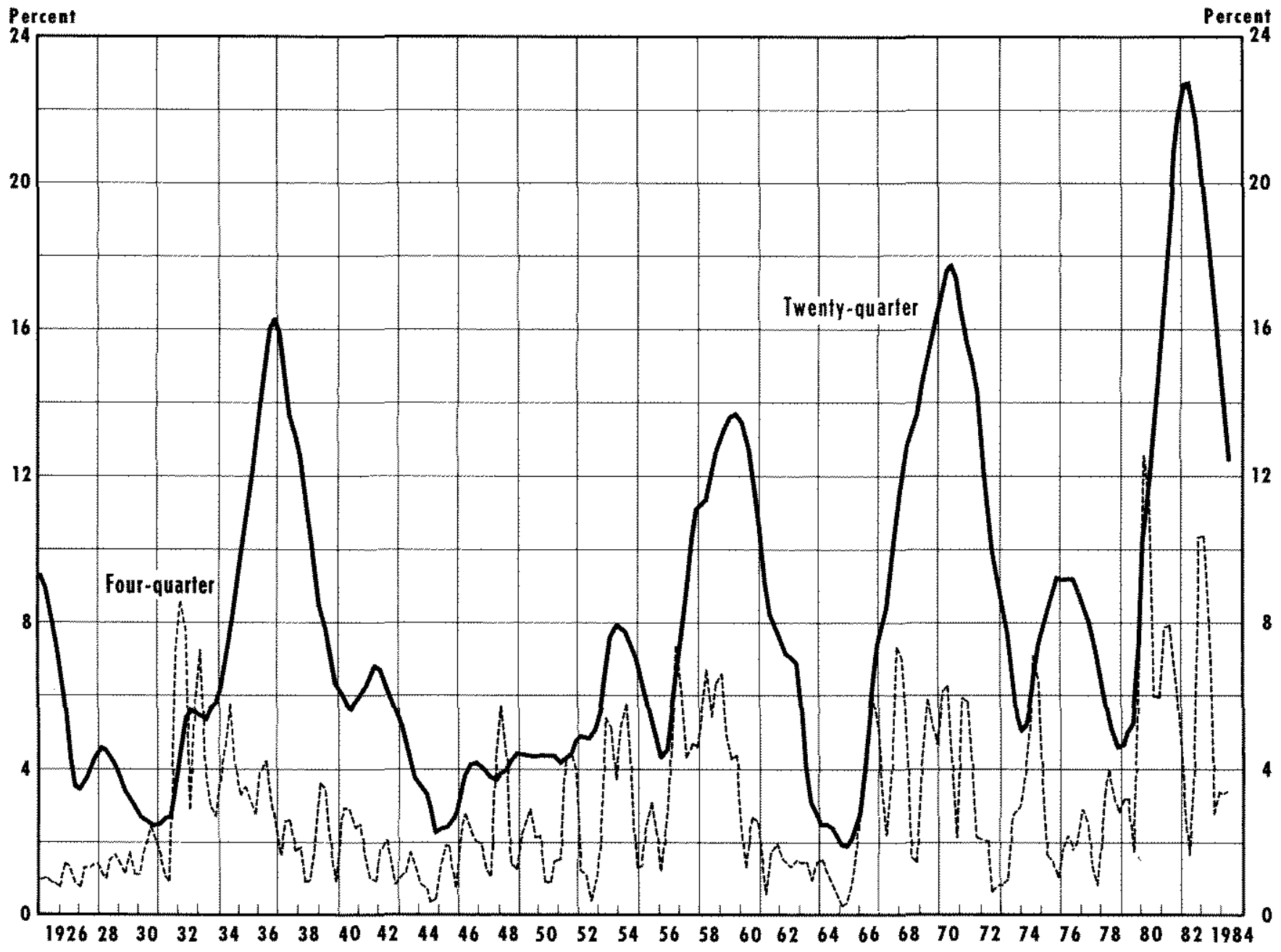

pretation is more accurately descriptive of risk perceptions following such level shifts in interest rates.

\section{The Link Between Variable Money Growth and Variable Interest Rates}

Both measures of the variability of money growth shown in chart 2 rose sharply beginning in 1980 and remained well above their previous average during $1980-83$. The variability of interest rates rose similarly, as chart 3 shows. An empirical investigation of the link between the variability of money growth and that of interest rates was conducted for the 20-quarter standard deviation measures shown in charts 2 and 3.

The best univariant time series model for VR is a second-order autoregressive and second-order moving average process during the periods $1 / 1955-\mathrm{V} / 1978$ and $\mathrm{l} / 1955 \mathrm{~m} / \mathrm{V} / 1983$.
Lags of the 20 quarter standard deviation of quarterly money growth shown in chart $2, \mathrm{VM}$, were introduced to test whether money growth variability influences interest rate variability, VR. The results for the period I/1955-IV/1983 are shown in table 1.

There is a significant positive link between a rise in the variability of money growth and the variability of interest rates. When one controls for the past two quarters of the variability of interest rates llonger lags

sThese tests, including past information on interest rate and money growth variability, use the Granger causality test specification. However, unidirectional causality is not asserted, necessary, or tested here. Also, interest rate variability may be a function of other sources of increased risk including increased variability of fiscal policy variables. The importance of other factors is apparent over the 1955 to 1978 period, when VR showed considerable variation, but VM was essentially unchanged. 


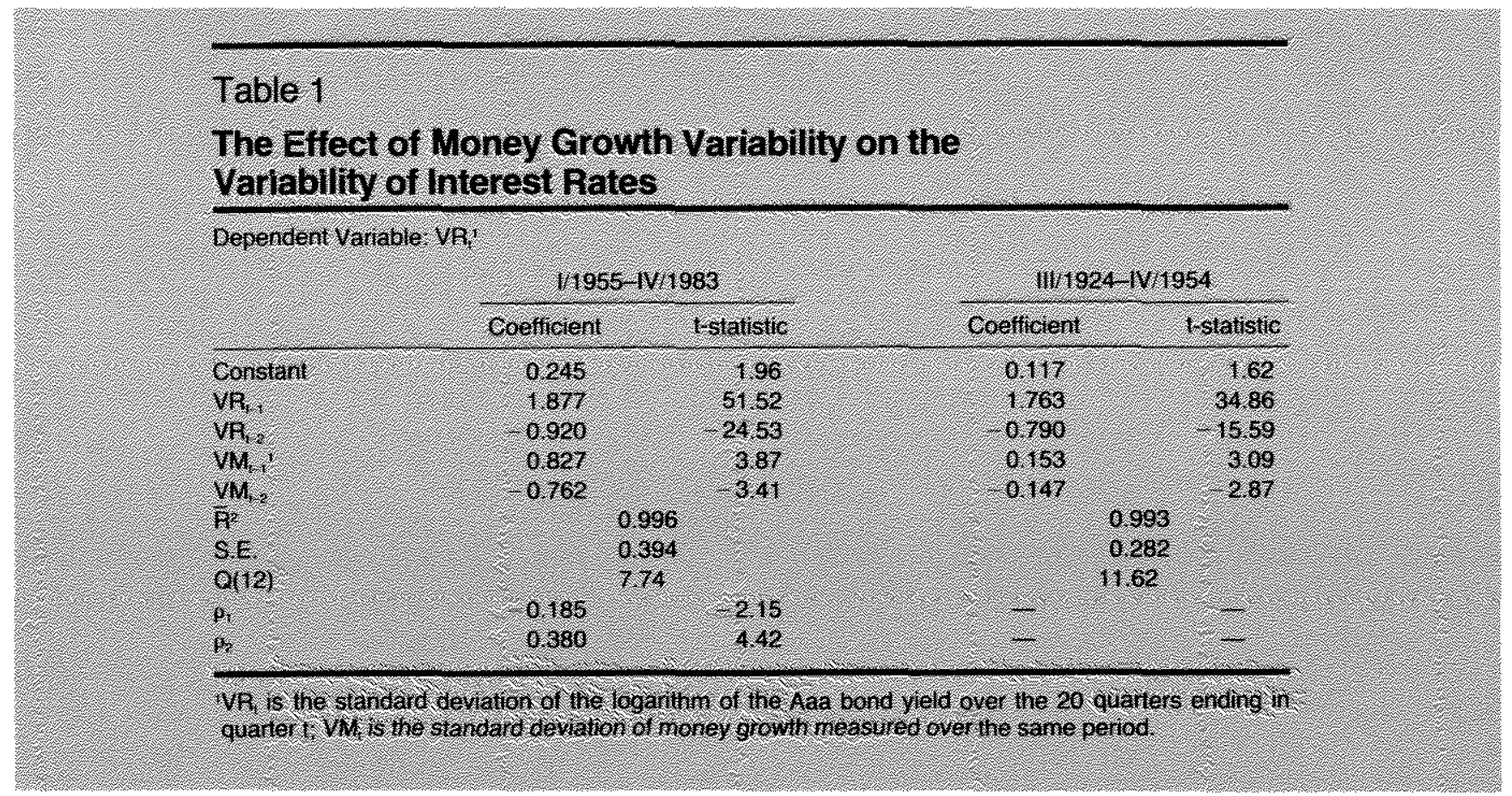

are not significantl and for statistically significant second-order autocorrelation, the variability of money growth over the previous two quarters has significant effects on the current level of the variability of interest rates." A rise in money growth variability initially has a significant and positive effect on interest rate variability; this effect is offset in the next quarter." According to table 1, the significant positive effect of the variability of money growth on interest rate variability is transitory."

Attempts to replicate the table 1 results from $/ 1955-$ IV/1978 were unsuccessful; the variability of money growth did not significantly affect the variability of interest rates over this earlier period. A principal rea-

\footnotetext{
'The Q-statistic indicates that the residuals in the equation estimate are not significantly correlated with their own past for up to 12 past quarters, although the same results holds for one to 24 past values of the residuals.

${ }^{10}$ The results do not arise from the computational relationship arising from the use of moving standard deviations. Virtually identical results are obtained by relating changes in $V R$ to $\Delta V R_{t-1}, V R_{t-2}$, and either $V M_{t-1}$ and $V M_{t-2,}$ or $\Delta V M_{1-1}$. First-differences of $V M$ or $V A$ are not computationally related.

"The steady-state response of VR to a rise in VM involves the lagged adjustment of VR to its own past values. This response is 1.52 , but its standard error, found from the variance-covariance structure of the coefficients on the lags of VM and VR, is 2.00 . Thus, the effect of a change in VM is transitory. Whether a rise in money growth variability, in theory, has a permanent or transitory effect on interest rate variability is a question that is not resolved here. The empirical evidence clearly indicates that the effect is transitory.
}

son for this result is that the variability of money growth over the period /1955-IIL/1979 was relatively constant; the standard deviation of VM over this period is 0.3 percent, only 15.3 percent of the mean level of money growth variability over the period. The variability of money growth from 1955 to 1979 was too small and steady to provide information on the potential impact of changes in money growth variability on interest rate variability."

\section{Earlier Evidence: 1924 to 1954}

Prior evidence of a systematic relationship between the variability of money growth and interest rates does exist, however. Friedman and Schwartz (1963) have shown that money growth variability was much greater before World War II than it was from the end of World War II to the early 1960s.". The variability of money growth also fluctuated much more before World War II. The average level of VM from 1/1924-IV/ 1954 is 7.5 percent, and its standard deviation is 3 percent; the former is more than three times as large.

12The mean of $\Delta V M$ from $1 / 1955-11 / 1979$ is 0.0021 and its standard deviation is 0.1101 . Over this period, $\Delta V M$ is an independently distributed random variable with a $\mathrm{Q}$-statistic, $\mathrm{Q}(12)$, of 7.34 , which indicates that $\triangle \mathrm{VM}$ is not correlated with its past history. Over the longer period to $\mathrm{V} / 1983, \Delta \mathrm{VM}$ is described by a first-order moving average process.

${ }^{ \pm 3}$ Friedman and Schwartz (1963, pp. 592-638). Their M1 data until 1947 is used to compute VM below. 
and the latter measure is about 10 times as large as that observed from 1955 to 1979 . Thus, this earlier period should provide useful information on the effect of monetary growth variability on interest rate variability.

Over the period III/1924-IV/1954, there is a statistim cally significant positive relationship between $V R$ and VM (see table 1). The results are similar to those for the 1955-83 period. In particular, for this eartier period, increases in the volatility of money growth temporarily and significantly raised the volatility of interest rates. Autocorrelated emors are not significant in the earlier period according to the Q-statistic. The dynamic structure for interest rate volatility is about the same as in the later period." The difference in the magnitude of the money growth variability effect in the two periods is not meaningful; the money stock data used in the early period are largely based on endof-month data, while those in the later period are based on averages of daily figures.

\section{VARLABILITY OF MONEY GROWTH AND INTEREST RATES: THE AGGREGATE DEMAND CHANNELS}

Mascaro and Meltzer (1984) have attributed part of the substantial jump in interest rates and the decline in real GNP growth in 1980-81 to the increased uncertainty arising from greater variability of money growth. They attribute a 1.3 percentage-point rise in the aver age long rate and a 3.3 percentagempoint rise in the average short rate over the nine quarters, IV/1979-IV/ 1981, to a rise in monetary uncertainty.

Mascaro and Meltzer emphasize a money demand channel for the effect of monetary uncertainty on the economy. A rise in monetary uncertainty increases the demand for money. They indicate that an increase in the demand for money raises the interest rate and reduces aggregate demand. In addition, they argue, prices and real output fall because of the reduction in aggregate demand. Furthermore, they suggest that the growth rates of output, prices and GNP are likely to be further affected by the reduced demand for capital. Their empirical analysis focuses on the rise in interest rates on both short-and long-term debt due to the risk premium. ${ }^{36}$

${ }^{94}$ Over this period, the t-statistic for the steady-state response of VR to $V M$ is 0.12 ; the response of $V R$ to $V M$ is transitory.

:Belongia has argued that nominal GNP growth was depressed by the rise in monetary uncertainty in 1980. Both Mascaro and Meltzer and Belongia use a measure of the variability of unanticipated money growth rather than that of actual money growth.
There is a second demand channel, however, through which money growth variability lowers investment. When money growth is more variable, the variability of the output of goods and services, employment and earnings will rise. There will also be greater risk associated with the expected retums from both existing capital and prospective investments. If stockholders and lenders are risk averse, and if existing expansion plans and sources of financing are to be maintained maket ates of refurn must rise to compensate for increased risk. Of course, with highes costs of capital funds and greater risk associated with pro spective investment projects, investment managers will both reduce investment and enhance the flexibility of their asset portfolios. "Thus, because it contributes to more volatile investment returns, erratic money growth raises the level of observed market rates and retards and redirects the desired stocks and usage of plant and equipment.

At unchanged interest rates and costs of funds for firms, a rise in the variance of expected returns from investment in plant and equipment reduces the in centive to invest. The portfolio shifts emphasized by Mascaro and Meltzer, and Gertler and Grinols (1982), involve an increase in money demand that maises in terest rates. Investment demand in their analysis declines along a given investment demand curve. But even at an unchanged cost of capital, firms faced with riskier expected incomes will reduce investment.

${ }^{16}$ Bodie, Kane and McDonald (1983) find evidence of a rise in the risk premium on long-term bonds. Gertler and Grinols (1982) show that a rise in monetary growth uncertainty raises money demand and reduces investment, but their result follows primarily from an increase in the variability of expected inflation, not from an increase in the variability of the real rate of interest. If variations in money growth affect real output and employment in the short run, as monetary explanations of the business cycle indicate, then monetary randomness also affects the variability of the expected real rate and investment incentives. Indeed, this is more likely if the link between money and prices has long lags as shown in the model used below or in Barro (1981). A rise in monetary variability raises the variability of yields on capital and reduces investment, either through increased variability of expected inflation or of real rates of return (both of which are captured in the variability of nominal interest rates), or both.

Makin and Tanzi attribute the high volatility of interest rates from 1980 to the end of 1982 to increased volatitity of both expected inflation and after-tax real rates of return. Their evidence for the former, however, is survey data on expected inflation for a six-month hotizon during a period in which substantial price level shocks were occurring.

TObviously a rise in risk tends to reduce both the supply of saving and investment demand at given market interest rates. Thus, the effect on observed market rates is not as straightforward as it may appear in the text. If suppliers of credit are more risk averse than firms that invest in plant and equipment, then market rates (not risk-adjusted) will tend to rise. This result also depends on relative interest elasticities of supplies and demands for credit and equities. 


\section{Figure 1 \\ The Channels of Influence of Increased Risk}

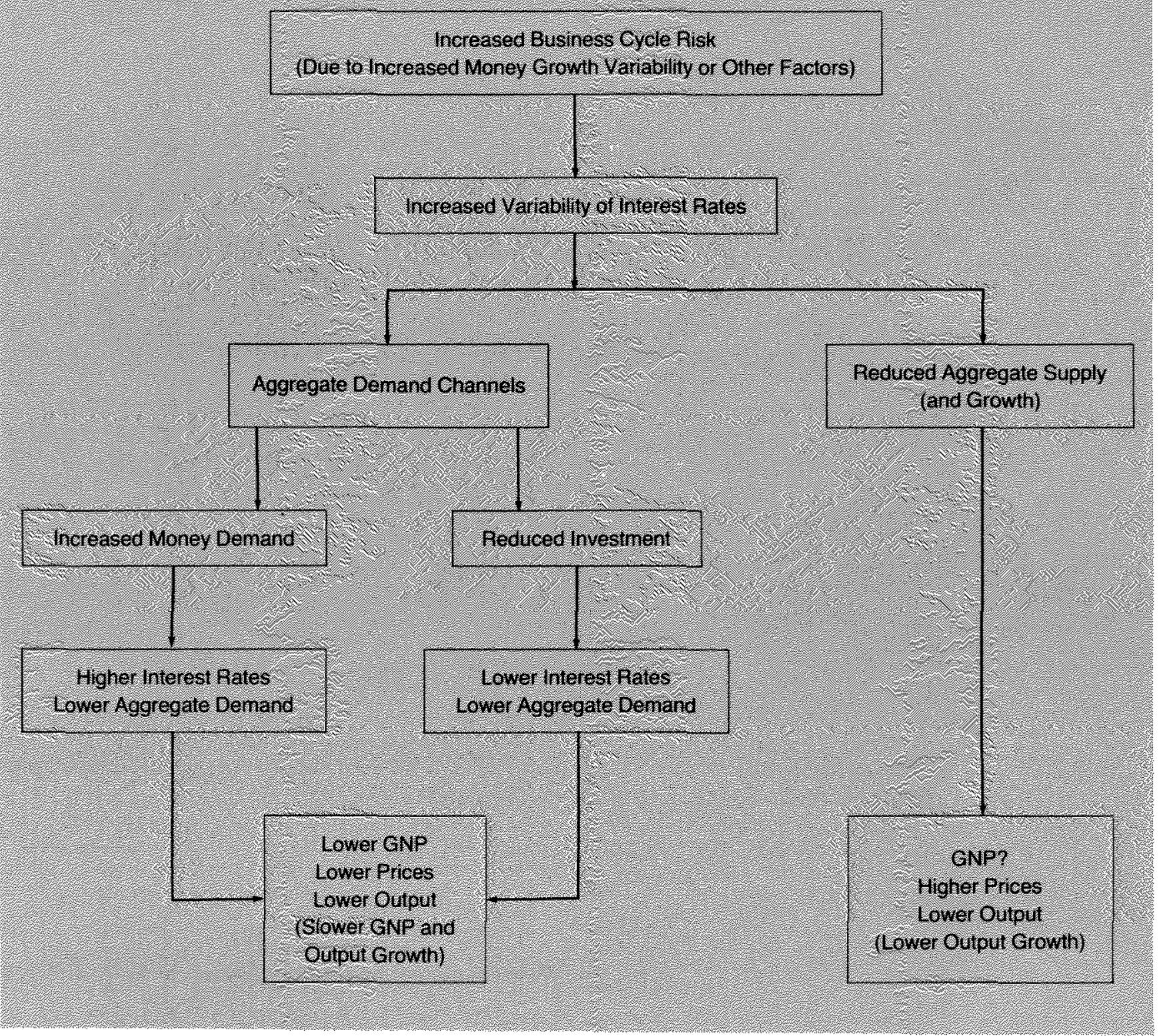

Such a decline in the demand for goods and services is accompanied by a reduction in the demand for credit, so that interest rates tend to fall along with aggregate demand.

The left side of figure 1 summarizes the two aggregate demand channels. These effects arise in this instance through increased money growth variability. Other changes that raise risk assessments about fu- ture economic conditions or business cycle risk could alter interest variability as well, however. There appear, then, to be at least two channels through which monetary growth variability affects aggregate demand: increased money demand and reduced investment. Of course, the two channels have opposite implications for interest rates; both, however, imply reduced aggregate demand and, hence, lower nominal GNP, real output and prices. The Mascaro-Meltzer evidence on 
interest rates suggests that the rise in money demand dominates risk-related reductions in the demand for goods and services.

Evans (1984) and Tatom (1984a) show that a rise in the variability of interest rates has a significant negative effect on the level of annual output. This effect is consistent with the two aggregate demand channels shown on the left side of figure 1 , but it encompasses other sources of a rise in such vartability besides a rise in monetary variability. To the extent that such variability arises from monetary variability, it simply reflects the channels through which money growth variability affects the levels of interest rates, spending, output and prices

\section{VARIABILITY OF INTEREST RATES AND MONEY GROWTH: AGGREGATE SUPPLY}

A rise in risk implies, at the produce level, increased variability of expected sales, real cash flows or profits. A rise in the variability of returns to production may be viewed as either an increased cost of using the firm's capital to produce output or a reduction in the value of given expected income. In either case, exposure to the increased risk can be lessened by reducing expected output, production and capital employment in production. Thus, an increase in risk reduces desired supply, given expected prices of inputs and output. ${ }^{*}$ This effect is summarized in the third channel of influence shown in figure 1 . Whether supply is reduced more than demand is not obvious. Thus, while the consequences of increased risk for spending and output are unambiguous, given the price level, the consequences for the price level are not.

Figure 2 shows the effect of a rise in risk, VR, on aggregate demand and supply. Initially, the economy is assumed to operate at point $A$ where, at price level $P_{0}$, the quantities of goods and services demanded and

${ }^{18}$ De Vany and Saving (1983) provide a model of the firm in which greater variability of demand will yield higher pecuniary prices, the substitution of inventory for plant and equipment at a given expected output rate to the extent the product is storable, and, a reduction in expected output resative to capacity. Such reductions in the efficiency of firms indicate an overall loss in economic capacity or, for a given stock of plant and equipment and employment, less expected output. The firm in their modet can be risk-neutral. Sandmo (1971) and Holthausen (1976) show that risk-averse firms reduce capacity and output in response to increased uncertainty, yielding similar price and output implications.
Figure 2

The Elfect of an Inerease in Risk on Output and Price

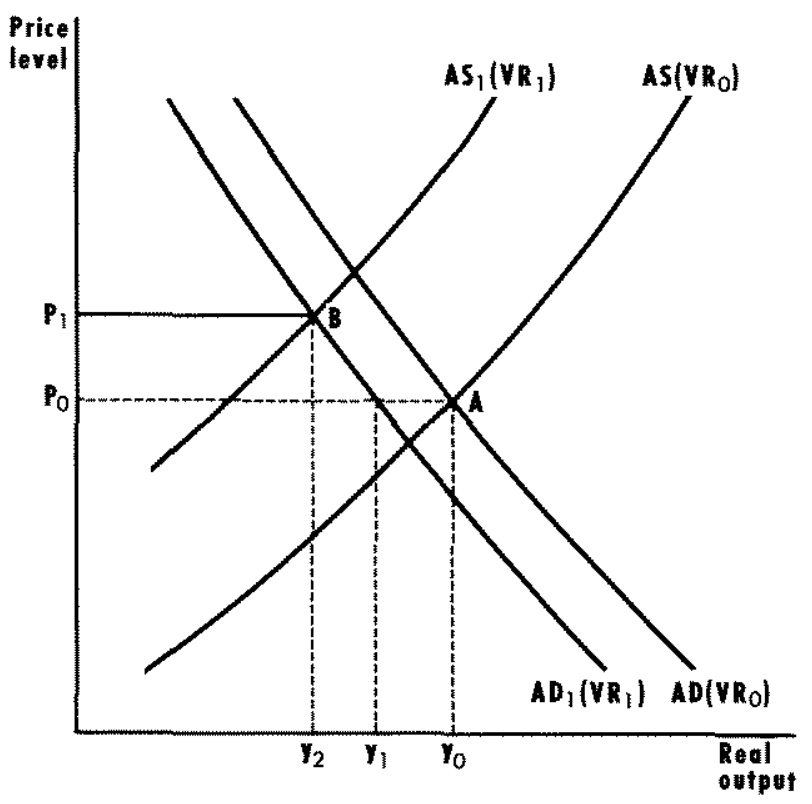

supplied $\left(y_{0}\right)$ are equal. An increase in risk reduces aggregate demand to $\mathrm{AD}_{1}$; at $\left(\mathrm{P}_{0}, \mathrm{y}_{1}\right)$, market interest rates, which are implicit in $A D$ and $A D_{1}$, are higher than at $\left(\mathbf{P}_{0}, \mathrm{y}_{0}\right)$. Aggregate supply is reduced as well, however. As drawn in figure 2 , AS shifts leftward more than $A D$, so the price level rises to $P_{1}$. Thus, the economy operates at point B. Of course, the price outcome depends on the relative magnitude of the supply and demand shifts.

Earlier studies of monetary uncertainty and interest rate variability have focused primarily on their effects on nominal and real GNP and on the interest rate. The common assumption appears to be that the effects on spending and output arise from an unanticipated shift in aggregate demand, so that the price level changes in the same dinection as spending or output. The model used below to assess the effects of interest rate variability is a reduced-form model for GNP, price and output growth that permits all three effects to be exam ined; this model is shown in table 2 .

In the model without interest rate variability, GNP growth depends on current and past growth rates of the money stock, cyclically adjusted federal expenditures, energy prices and a strike variable." Inflation 


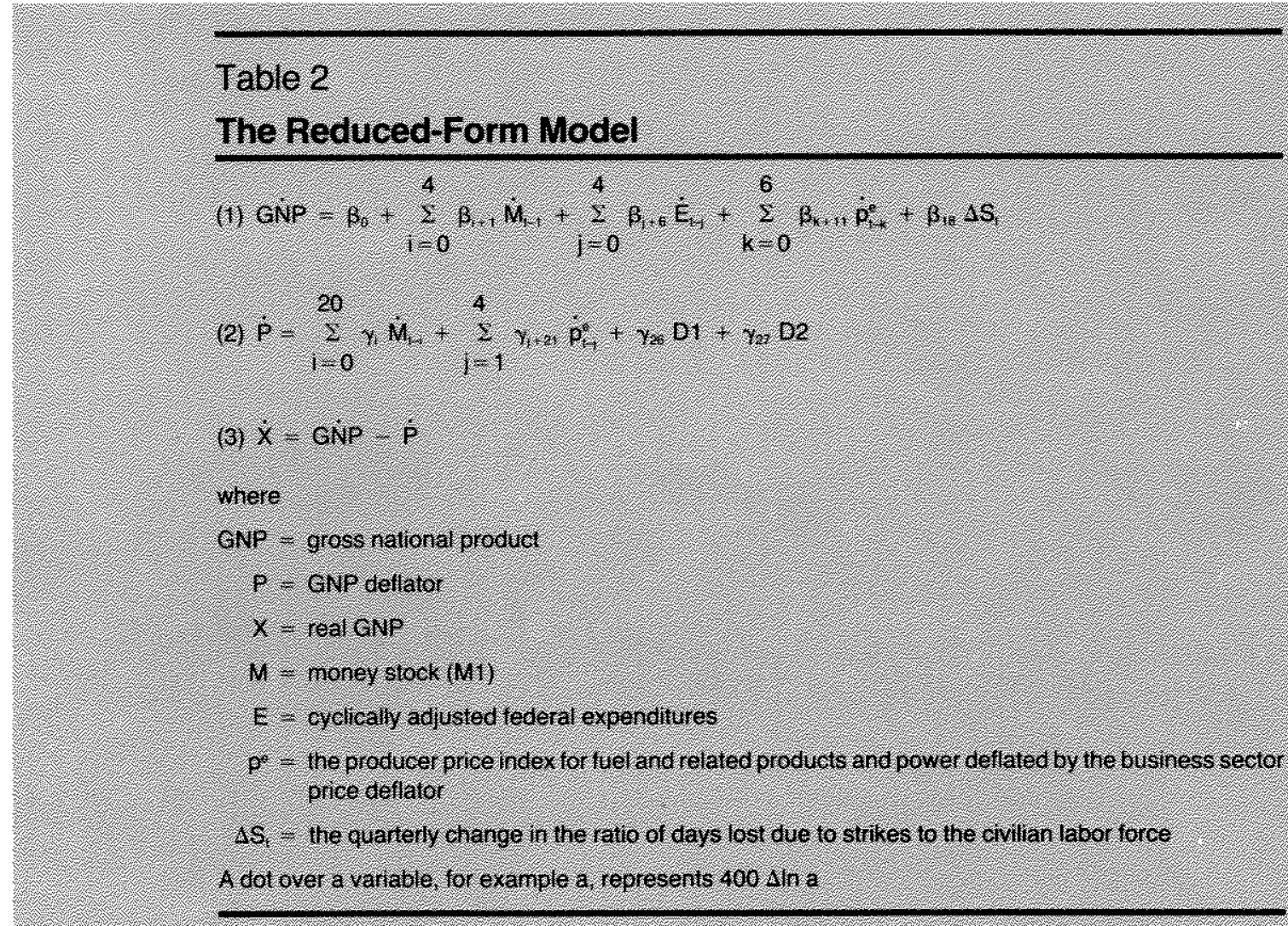

depends on current and past growth rates of the money stock, energy prices and dummy variables for the wage-price control and decontrol periods of the early 1970 s.

Introducing interest rate variability into this model permits its effects on GNP and the price level to be examined directly. The real output growth effect simply equals the difference between the GNP growth and inflation effects. In addition, the equation in table 1 (1/1955-IV/1983) can be used to delineate anticipated and unanticipated interest mate variability. Thus, the issue of whether interest rate variability effects arise from unanticipated or anticipated changes in variability can be examined.

19The model estimation uses quarterly data for growth rates. Evans and Tatom (1984a), use annual data for the level of output and, in the latter, the level of prices.

The strike variable, $S$, is based on days lost due to work stop. pages. The detaiss for its construction are available upon request from the author. The coefficients for money and expendifure growth were estimated using a fourth-degree polynomial with head and tall constraints. The energy price coefficients were estimated using a third-degree polynomial and were constrained to sum to zero. This constraint cannot be rejected in either period.

\section{INTEREST RATE VOLATILITY AND ECONOMIC PERFORMANCE}

To examine whether recent changes in interest rate variability affected total spending or GNP, tine modified version of the Andersen-Jordan equation shown in table 2 was used for GNP. Since interest rate variability rose sharply beginning in 1979 , tests were conducted for two periods: V/1955-IV/1978 and I/1955IV/1983.20

The results for GNP growth are given in table 3 . In both periods, a rise in the variability of interest rates in

\footnotetext{
${ }^{20}$ The level of interest rates can be controlled for in tests such as these, but this raises an identification problem; a change in interest rate variability affects the level of interest rates and vice versa. Such an attempt to control for interest rates would capture variability effects in the interest rate effects, or vice versa. The interesi rate specification in Tatom (1983), the contemporaneous and five lagged values of the changes in the logarithm of the Aaa bond yield, was added to the GNP equation in table 3 to check for their importance. The lagged variability of interest rate measure remains significant in both periods, despite the inclusion of these interest rate controls $s_{1}$ so that the resuts reponted do not arise from changes in the level of interest rates. Similar controls were examined for the price equation; see footnote 28 below.
} 


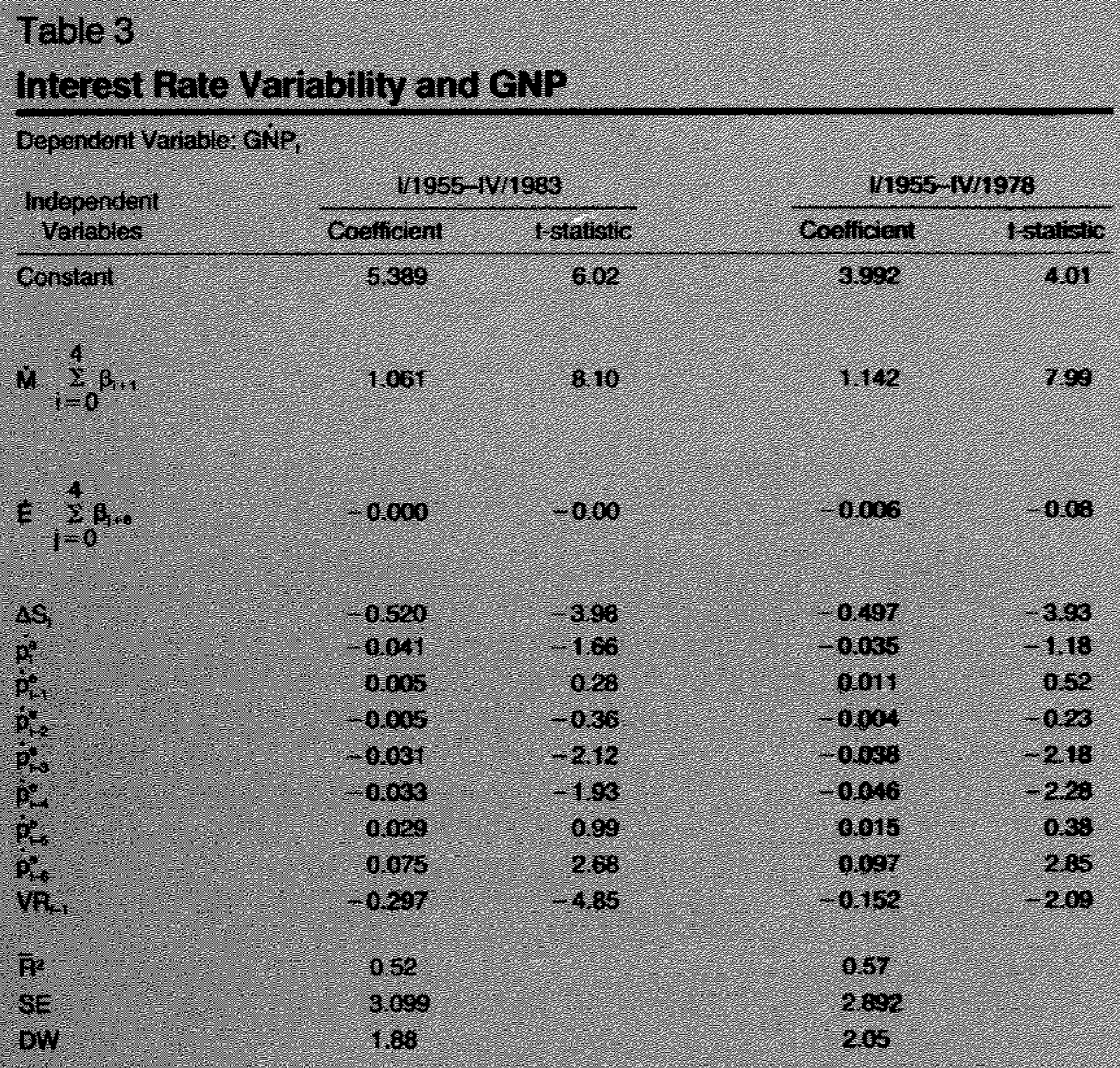

the previous quarter significantly and permanently reduces the growth rate of GNP." Longer lags lup to eight quarters) on the variability of interest rates were examined, but none added significantly to the table 3 equation, with or without an insignificant contemporaneous term. In the more recent period, the effect is larger than in the pre-1979 sample period, but both results indicate that variability matters. The equation in table 3 was also estimated to the third quarter of 1981, the previous cyclical peak. The coefficient on interest rate variability, $\mathrm{VR}_{1-1}$, is about the same as in the pre-1979 case, -0.138 it $=-2.03$; t thus, the change

${ }^{21}$ For the longer period (1/1955-IV/1983), the coefficient of a contemporaneous fouf-quarter standard deviation of interest rate changes is significantly negative in the GNP growth equation. The lagged value of the average absolute change in the level of interest rates also significantly and negatively affects GNP whether measured over four, 12 or 20 quarters, and in both periods. None of the fatter measures provide as much explanatory power as VR in the text. in the volatility coefficient occurred as a result of the experience from mid-1981 to the end of 1983.

The variability measure $\mathrm{VR}_{4}$ can be decomposed into an anticipated component, $\mathrm{VR}$, the predicted value from the 1/1955-IV/1983 estimate in table 1 , and an unanticipated component, $\mathrm{VRE}_{\text {, }}$, the residual from the equation. The tests of the GNP effect can be conducted using each of these measures to clarify the source of the interest rate variability effect. While either effect is consistent with the theory, the importance of monetary variability as a major source of the GNP effect is strengthened if it is found that the anticipated compo-

2The equation estimated to the end of 1978 is stable when extended to III/1981. The $F$-statistic for the additional 11 observations is $F_{1183}$ $=0.93$. When the equation ending in II/ 1981 is extended to IV/ 1983, it is not stable; the F-statistic for the additional nine observations is $F_{\text {ig }}=2.89$. The critical $F$ is 1.98 (5 percent) or 2.60 (1 percent). The instability of the equation during late 1981 and 1982 is also discussed in Tatom (1984b). 
nent of variability, which depends, in part, on money growth variability, is responsible for the GNP effect.

Tests of current and lagged values of both VR and VRF were conducted. It might seem that only the anticipated and unanticipated components of $V R_{\mathrm{v}-1}$ should be examined because it is the significant variable in table 3 . But $V R$, and lagged VR terms beyond one lag are constrained to zero in table 3 , a result that may only have been supported in the lag search over VR by constraining the anticipated and unanticipated component to be equal in each of the omitted periods. Thus, it is useful to examine all of lags of Vh and VRE, regardless of the actual VR lags selected above. Current or lagged values of unanticipated volatility, VRE, are not statistically significant in either period, whether anticipated interest rate variability is in cluded or not. The current or first lag of anticipated volatility, $V \hat{R}_{1}$ or $\hat{V R}_{t-1}$ are significant, in both periods; additional lags are not significant for either specification in either period.

The results using either $\hat{V R}_{1}$ or $\hat{V R}_{1-1}$ are virtually identical those using $V R_{\text {, }}$ are reported here. The coefficient on $\hat{V R}_{1}$ is $\left.-0.158 \mid t=-2.18\right)$ in the $\mathrm{V} / 1955-\mathrm{V} / 1978$ period and $-0.289(t=-4.75)$ in the longer period. Both estimates are essentially identical to those shown for $V_{t, 1}$ in table 3 . Further, none of the other coefficients in table 3 are affected when $\hat{V R}$, is used and the standard error of the estimates compare favorably. In the period ending in IV/1983, the standard error is 3.111 ; $\mathrm{th}$ the earlier period it is 2.886 . The adjusted $R^{2} s$ are the same as in table 3 . Thus, the source of the interest rate variability effect in table 3 is anticipated variability. The results indicate that the effect of interest rate variability on GNP growth since 1979 discussed below is the same whether the measure chosen is the actual past level of volatility, $V R_{t-1}$, or contemporaneous or lagged anticipated volatility $\left(\hat{V R}\right.$ or $\left.\hat{V R}_{1, s}\right)$.

\section{Some Problems with the GNP Estimates}

It should be noted that the interest rate variability measure, either $V R_{1-1}$ or $V R_{1}$, enters the GNP equation in level form. Thus, a rise in the level of VR permanently affects the growth rate of nominal GNP. Tests of additional lags, especially $V R_{k^{\prime 2}}$ and $V \hat{R}_{1, \ldots,}$, respectively, indicate that they are insignificant. This result suggests that a permanent rise in the variability of interest rates reduces both the level of GNP in the short run and the growth rate of spending permanently.

\footnotetext{
${ }^{23}$ The significance of $\hat{V R}$ in both periods indicates that, given past interest rates, VM significantly reduces GNP. When VM and its lags are added alone to the table 1 equations, however, they are not significant.
}

The latter effect is theoretically implausible; the capital stock eventually should be adjusted to its lower desired level. Once this has occurred, the permanent effect on the growth of nominal spending and real output should disappear. The dynamic structure of VR indicates, however, that interest rate volatility tends to revert to its mean following changes in money growth variability or random shocks. Thus, because changes in interest rate volatility are transitory, changes in the GNP growth rate arising from interest rate variability are transitory as well.

A second concern with the GNP evidence is that variability measured over two shorter time horizons (four and 12 quarters) does not have a significant effect on GNP growth, nor do a few other measures of variability for any horizon. There are two ways to interpret the GNP results. One interpretation is that changes in interest rate variability are only important when viewed from a longer lime horizon and even then, only certain measures of variability (such as VR, the coefficient of variation of the interest rate of average absolute changes in the interest ratel capture the relem vant risk. The other alternative is that the GNP results are spurious. The consistent results from the tests for prices below suggest that the latter interpretation is not valid.

\section{The Effect of Interest Rate Variability on Prices}

The theoretical discussion indicates that the effect of increased interest rate variability on prices is an empirical issue; it depends on whether aggregate supply is affected more or less than aggregate demand. To assess this relationship, a standard price equation which emphasizes the link between money growth and prices, controlling for shocks such as wage and price controls and energy price changes, is employed. The price equation used for the test of an interest rate variability effect is the second equation in table 2.-Again, both permanent and transitory effects of interest rate variability were examined.

As with the GNP experiments, the five-vear measure

\footnotetext{
${ }^{24}$ The coefficients on money growth are estimated to lie along a thirddegree polynomial.

${ }^{25} \mathrm{~A} 12$-quarter measure of the standard deviation of the logarithm of the interest rate has a positive and statistically significant effect at one lag in the period ending in IV/1983, but the equation has a higher standard error than the same estimate using the 20-quarter variability measure. The 20 - and 12 -quarter average absolute change in the interest rate also significantiy raises then lowers inflation at lags one and two, respectively, over the longer period, but no effect is significant in the earlier period. See also footnote 31 below.
} 


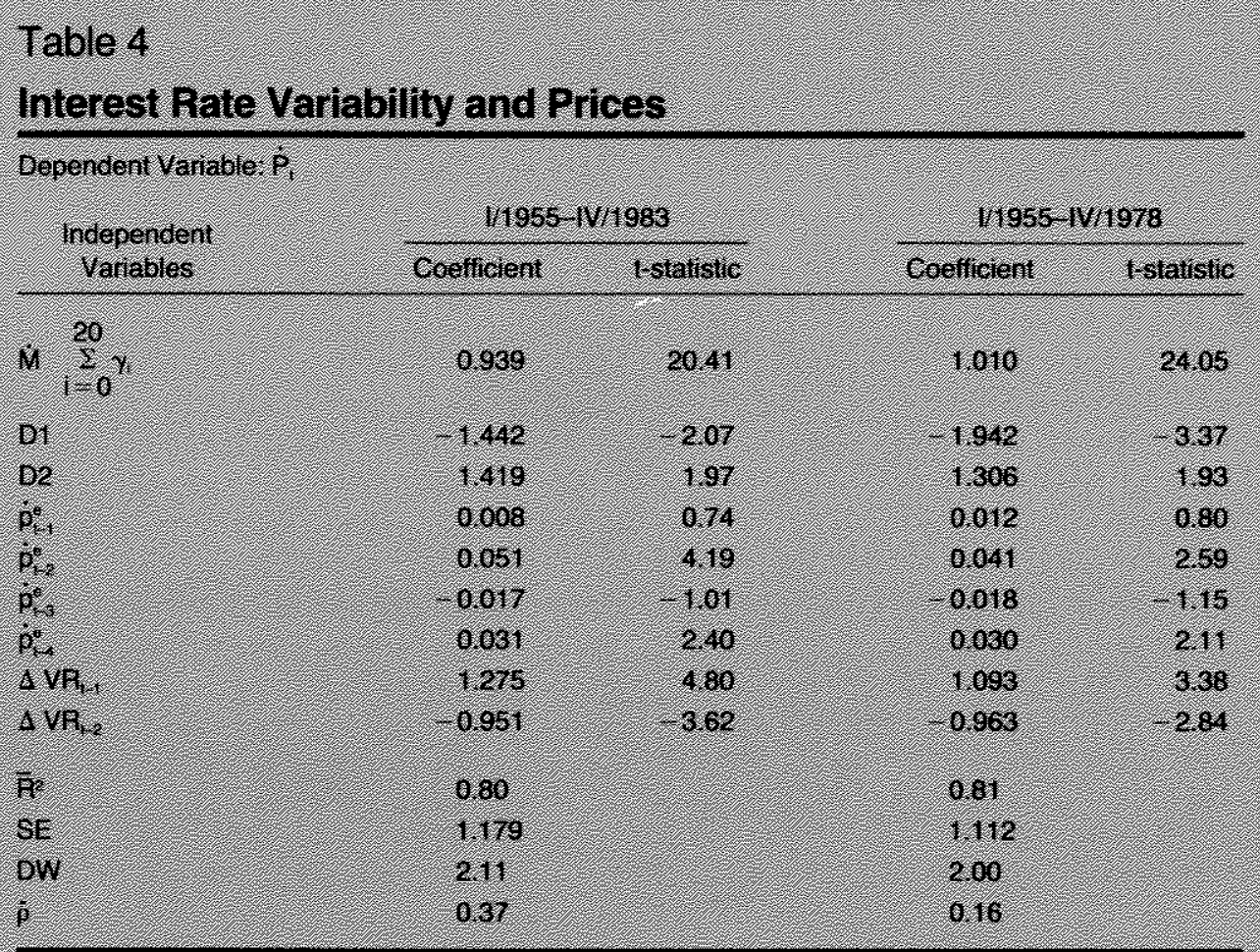

of variability (VR) is significant and provides the greatest explanatory power of the alternative measures. ${ }^{35}$ Tests for statistically significant lags of VR indicate that the past three quarters of interest rate volatility affect inflation. The effects of VR sum to zero, implying that there is no permanent effect of a change in VR on inflation. ${ }^{: 5}$ Thus, the appropriate expression includes $\Delta V R_{t-1}$ and $\Delta V R_{t-2 .}$ The price equation results for the two periods are summarized in table 4. In addition, these results indicate that there is no permanent effect of a change in VR on the level of prices, since the coefficient on $\Delta V R_{t-1}$ is opposite in sign and statistically not significantly different from that for $\Delta \mathrm{VR}_{1-3}$.

According to these results, a rise in VR initially raises inflation and the price level one quarter later, then depresses inflation and the price level in the subsequent quarter. After two quarters, both inflation and

\footnotetext{
${ }^{26}$ The F-statistics for this constraint are $F_{1.84}=0.85$ for the $1 / 1955$ IV/1978 period and $F_{1,105}=0.00$ in the $/ / 1955$ IV/1983 period.

${ }^{27}$ This result is at odds with that found using annual data where interest rate variability appears to have a permanent positive impact on the price level. See Tatom (1984a). It is shown below, however, that a distinction between anticipated and unanticipated variability yields results that are consistent with the annual result for the price level.
}

the price level are unaffected. ${ }^{2 \pi}$ The sum of the coefficients on the change in interest rate variability in table 4 is positive, but not significantly different from zero. In the $\mathrm{L} / 1955 \mathrm{~m} / \mathrm{V} / 1978$ period, the sum is 0.130 $(t=0.62)$, while in the $\mathrm{V} / 1955-\mathrm{IV} / 1983$ period it is 0.283 $(\mathrm{t}=1.27)^{* *}$

The anticipated/unanticipated variability distinction was also employed to isolate the inflation effect. When $V R_{t-1}, V R_{1-2}$ and $V R_{1-i}$ are decomposed into anticipated and unanticipated components using the table 1 equation, only the lagged unanticipated component,

\footnotetext{
${ }^{28}$ The price equation is stable across the two periods in table 4 . The $F$-statistic for the last 20 observations is $F_{x 0.83}=1.66$, which is below the critical value of 1.69 ( 5 percent significance level). The equation is not stable without the interest rate variability term. See Tatom (1984b), where tests of other variables (such as shifts to other checkable deposits or unusual recent movements of exchange rates, the volatility of money growth, unemployment or interest rates) that might affect prices indicate that, since mid 1981, only unemployment and the previous quarter's change in the in of the Aaa bond fate significantly affect the price level. The unemployment result does not hold before IV/1981 and disappears even in the later period when the past interest rate change is included. The bond yield result is robust across the periods. When either of these variables is added to the estimates in table 4 , however, it is not significant in either period, and the interest rate variability result is unaffected. This also indicates that controling for the level of interest rates in table 4 does not affect the result there.
} 
$V R E_{t-1}$, is significant, and in both periods. Tests of lags of VRE or VR vielded the same conclusion for VRE and indicated that both $\hat{V R}_{t}$ and $\hat{V R}_{t-1}$ terms are statistically significant in both periods. In addition, the coefficients on the two anticipated variability terms can be constrained to sum to zero; in the $1 / 1955-\mathrm{IV} /$ 1978 period, $F_{1, \pi}=0.00$, while in the longer period, $F_{1,14}$ $=0.70$.

The inflation equations with $V_{R E_{1-1}}$ or $\Delta V \hat{R}_{1}$ are given in table 5 , along with the inflation equation containing both variables." The results do not dis" criminate between the altemative hypotheses that only anticipated ( $\triangle \mathrm{VW}$ ) of unanticipated (VRE) interest rate variability matters in the $/ 1955-\mathrm{IV} / 1983 \mathrm{period}$. Either specification yields the same adjusted $\mathbf{R}^{2}$ and standard error of estimate; when one of these variables is included, the other is not significant. In the earlier period, however, lagged unanticipated volatility slightly outperforms the anticipated variability specification. Moreover, the tests show that when $\mathrm{VRE}_{1-1}$ is included, information on anticipated variability is not statistically significant.

The effect of interest rate volatility on prices is unambiguous, according to the results in table 5 . In particular, a rise in anticipated variability temporarily raises inflation, leaving the price level unambiguously higher. Although it may appear that a rise in unanticipated variability permanently raises prices and inflation, only the former conclusion is correct; this result is the same as that obtained when only anticipated inflation is considered. A rise in the unanticipated variability of interest rates cannot permanently raise inflation because, by definition, the level of unanticipated variability is only a transitory phenomenon.

The evidence supports the dominant supply side

${ }^{2}$ In table 4 , the included lags of VR can be written as (VR, $V R_{1-1}$, $V R_{t-2}, V R_{1-3}$, where the coefficient on $V R_{1}$ is constrained to zero. $A$ more general specification includes the anticipated (VR) and unanticipated component (VRE) of each of the VR effects above, where these components at each lag are not constrained to be equal. From this specification, the constraints involved in table 5 can be tested and found to hold. These constraints are that the coefficients on

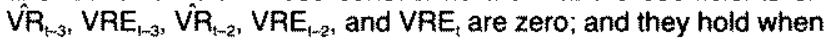
tested jointly or separately. One cannot discriminate statistically between the hypotheses that the coefficients on $\hat{V A}_{t}$ and $\hat{V F}_{t-1}$ are significantily different from zero and opposite in sign while that on $V R E_{t-1}$ is zero and the hypotheses that the coefficient on VRE $E_{t-1}$ is significantly different from zero and those on $\hat{V} R_{1}$ and $\hat{V} R_{t-1}$ equal zero. An implication of these results is that the apparent insignificance of $V P_{1}$ in table 4 arises from the imposition of the unsupportable constraint that the effects of VR, and VRE, are the same. Thus, the following constraints in table 4 do not hold: that the coefficient on $\hat{V} R_{1}$ is zero or that the coefficients on $V F_{t-1}$ equals that on VRE When these constraints are relaxed, both components of $V R_{1-2}$ and $V_{R_{t-3}}$ drop out. effect of interest rate variability: a rise in interest rate variability unambiguously raises prices permanently, through a temporary rise in inflation, but it has no permanent effect on the inflation rate. The evidence, however, does not discriminate well between whether the permanent effect on prices arises from changes in anticipated variability or past unanticipated variability.

\section{The Effect of Interest Rate Variability on Output}

The growth rate of real GNP in the model in table 2 equals the difference between the growth rate of GNP and the growth rate of prices; it can be written as the right-hand-side of the GNP equation less the righthand-side of the price equation. Consequently, the effect of interest rate volatility on output growth is the difference in the VR components in the appropriate GNP and price equations.

Since a permanent rise in interest rate variability pemanently lowers the growth rate of GNP and temporarily raises the inflation rate, the permanent effects on real output and its growth rate are unambiguously negative. An estimate of the effect of interest rate variability on output growth is found using the actual variability results in tables 3 and 4 . For the $/ / 1955-I V / 1983$ period, the output growth effect is $1-1.572 \Delta V R_{1,1}+$ $0.654 \Delta \mathrm{VR}_{1-2}-0.297 \mathrm{VR}_{t-3} ;$; $\mathrm{t}$-statistics for the three coefficients are $-5.76,2.42$ and -4.87 , respectively. When the anticipated interest rate variability measure results are combined, the real GNP growth rate effect is $\left(-0.937 \Delta V \hat{R}_{1}-0.289 \hat{V R}_{i-1}\right)$; the t-statistics for the two coefficients are -5.78 and -4.75 , respectively. The longmun effect on the real GNP growth rate indicated by the last term is essentially identical for both specifications, while the timing and short-run effects are slightly different. Of cotrse, the same effects can be estimated using the unanticipated volatility effect on prices and the anticipated volatility effect on GNP; when this is done, once again, the differences are slight.

\section{The Estimated Effects on Economic Performance: $1980-83$}

To gain some insight into the magnitude of the estimated effects above, the actual levels of $V R_{1}$ from $1 / 1980$ to IV/1983 are given in table 6 , along with the effects on the growth rates of GNP, prices and real GNP, due to the departure of VR from its I/1955-III/1979 mean level of 8.60 percent. The effects for GNP, prices and output 


\section{Table 5}

\section{Anticipated and Unanticipated Interest Rate Volatility and Inflation}

Dependent valablo.

$119556=111988$

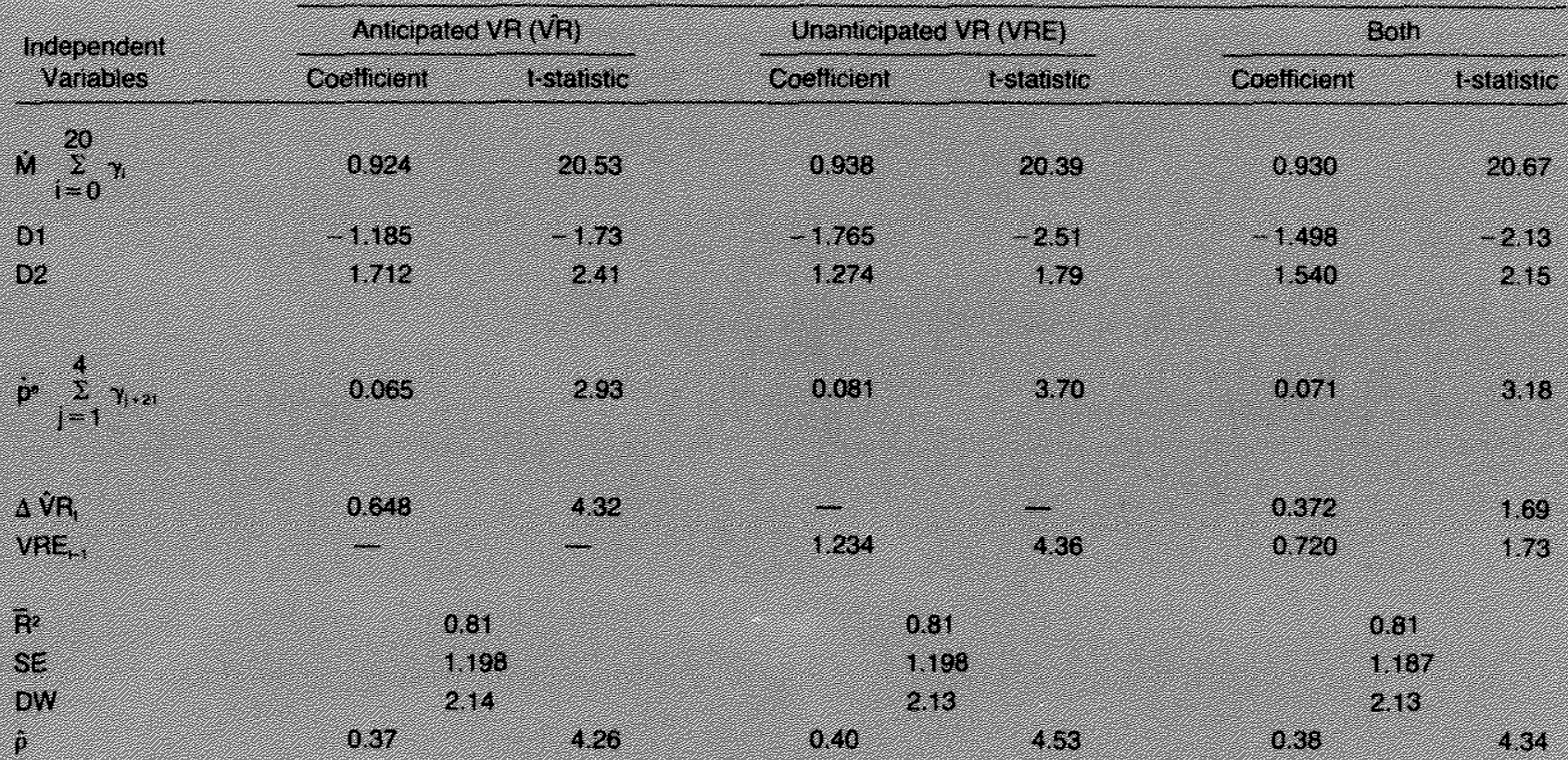

$110956-111978$

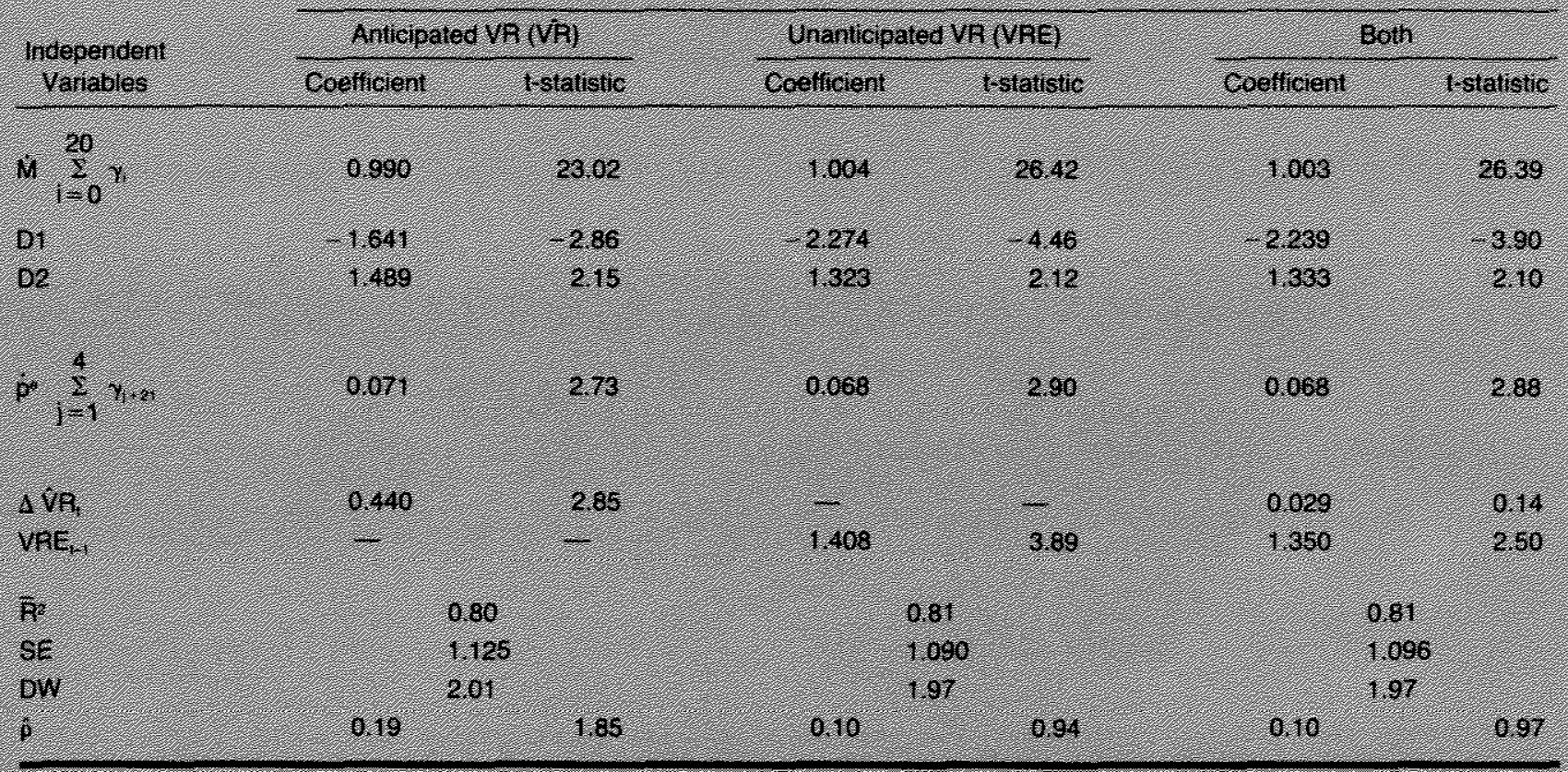




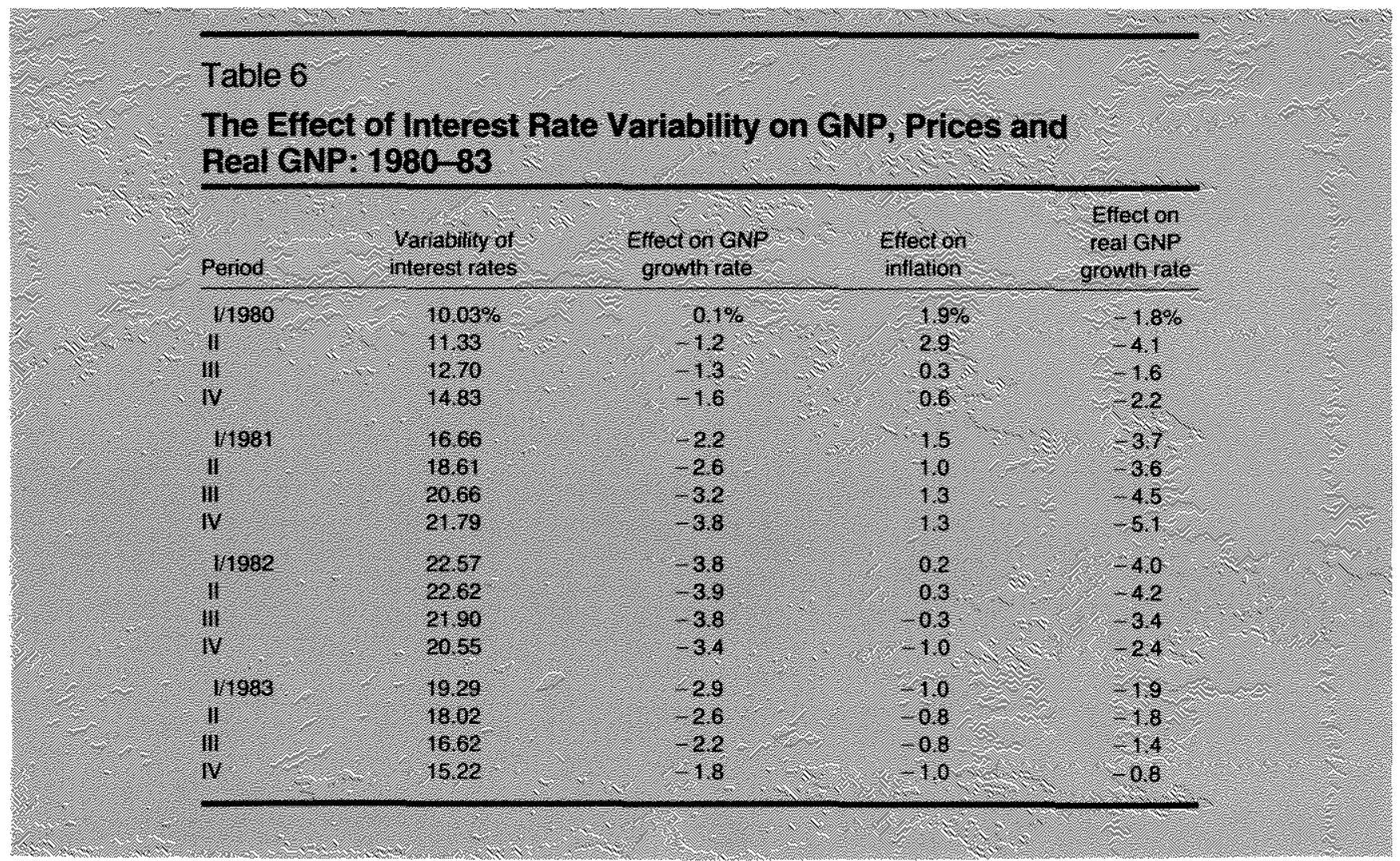

in table 6 use the 1/1955-IV/1983 estimates of the impact of anticipated variability reported above. The estimates based on actual or unanticipated variability effects are about the same for the whole period or for subperiods such as the $1981-82$ recession.

Changes in risk, as measured by the five-year standard deviation of the logatithm of Aaa bond yields have had a substantial impact on the economy since 1979 , generally retarding the growth rate of nominal and real GNP over the period. In 1980-81, the rise in risk temporarily raised the observed inflation rate. The subsequent fall in risk temporarily reduced inflation in $1982-83$.

Table 6 indicates that greater interest rate variability reduced the growth rates of nominal spending and real GNP by an average of 2.3 and 3.8 percentage

\footnotetext{
${ }^{30}$ Evans also reaches this conclusion. Using the estimates based on actual variability, the reduction in nominal GNP over the whole period shown in table 6 is 2.7 percentage points, while during the recession it is 3.9 percentage points; the reduction in real GNP growth over the whole period is 2.8 percentage points and 3.6 percentage points during the recession. Sirnilar estimates are found using the unanticipated interest rate variability hypothesis for prices; real output falls 2.6 percentage points over the whole period and 3.7 percent during the recession.
}

points, respectively, during the III/1981-IV/1982 recession. ${ }^{30}$ Thus, such variability played a major role in the relatively sluggish growth of spending at a 2.8 percent rate over the period and the -2.4 percent growth rate of real GNP from peak to trough. Indeed, departures from the mean variability had a negative impact on real output growth that exceeds the observed decline, suggesting that, in the absence of increased variability, real GNP growth would have been positive. ${ }^{31}$

\footnotetext{
3t When the measure of variability is the 20-quarter standard deviation of the changes in the logarithm of the quarteriy interest rate, similar significant effects are obtained for GNP, prices and real GNP. Over the period $1 / 1955-\mathrm{IV} / 1983$, the current and past four leveis of this standard deviation measure significantly affect GNP growth. The sum effect is significantly negative. in the price equation, only the change in the standard deviation three quarters earlier is significant. For both equations, the statistical results are inferior to those presented in the text, judged by the fit of the equations. Also, the results are not as robust. In the $1 / 1955-I V / 1978$ period, no lag of this measure adds significantly to the price equation; in the GNP equation, only the lagged change in the standard deviation approaches significance ( $t=-1.92$ ). The quantitative effects of higher variability on GNP, prices and output using this measure, however, are similar to those found from tables 3 and 4 or those given in table 6 . For example, over the recession period $1 / 1 / 1981-\mathrm{IV} / 1982$, nominal and real GNP growth were reduced by an average 2.7 percent, while inflation was unaffected. The anticipated/unanticipated variability tests were not conducted for this measure due to the inferiority of the actual variability results.
} 


\section{SUMMARY AND IMPLICATIONS}

The evidence here generally supports recent studies which indicate that increased variability of money stock growth and interest rates in the early 1980 s had deleterious effects on output and employment. Moreover, the evidence provides a link between the rise in money growth and interest rate variability. The rise in the variability of interest nates, in particular anticipated variability, was an important channel through which increased monetary uncertainty operated to reduce GNP, output and employment, and to first raise, then lower, inflation after 1979.

The empirical results suggest that the rise in interest rate variability after 1979 explains the severity of the 1981-82 recession. The results also shed some light on the magnitude of the swing in observed in flation from 1980-81 to 1982-83. Inflation was first pushed up temporarily in 1980-81, then down in 1982-83 due to the pattern of changes in interest rate volatility since 1979 .

\section{REFERENCES}

Barro, Robert J. Money, Expectations and the Business Gycie (Aca demic Press, 1981 ).

Batter, Dallas S., and Courtenay C. Stone. "Are Monetarists an Endangered Species?" this Review (May 1983), pp. 5-16.

Belongia, Michael T. "Money Growth Variability and GNP," this Review (April 1984), pp. 23-31.

Board of Governors of the Federai Reserve System, Federal Reserve Staff Study, New Monetan Control Procedures (February 1981).

Bodie, Zvi, Alex Kane, and Robert McDonaid. "Why Are Real inter. est Rates So High?" National Bureau of Economic Research Working Paper \#1141, (June 1983).

Bomhoff, Edward J. Monetary Uncertainty (Elsevier Science Publishers B.V., 1983).

Cartson, Keith A. "A Monetary Analysis of the Administration's Budgel and Economic Projections," this Review (May 1982), pp. 3-14.

De Vany, Arthur $S$, and Thomas R. Saving. "The Economics of Quality," Joumal of Political Economy (December 1983), pp. 9791000.

Evans, Paul. "The Effects on Output of Money Growth and interest Rate Volatility in the United States," Journal of Poffitical Economy (April 1984), pp. 204-22.

Friedman, Mitton. "What Could Reasonably Have Been Expected From Monetarism: The United States, " presented to The Mont Pelerin Sociely, 1983 Regional Meeting, Vancouver, Canada, August 1983 and Anna Jacobson Schwartz. A Monetary History of the United States, 1867-1960 (Princeton University Press, 1963).

Gertler, Mark, and Eart Grinols. "Monetary Randomness and Investment," Joumal of Monetary Economics (September 1982), pp. $239-58$.

Gibert, R. Alton, and Michael E. Trebing. "The FOMC in 1980: A Year of Reserve Targeting," this Review (August 1981), pp. 2-16.

Hein, Scott E. "Short-Run Money Growth Volatility: Evidence of Misbehaving Money Demand?" this Review (June/July 1982), pp. $27-36$

Holthausen, Duncan M. "Input Choices and Uncertain Demand," American Economic Review (March 1976), pp. 94-103.

Lang, Richard $W$. "The FOMC in 1979: Introducing Reserve Targeting," this Review (March 1980), pp. 2-25.

Makin, John $H$, and Vito Tanzi. "The Level and Volatility of Interest Rates in the United States: The Role of Expected Inflation, Real Rates, and Taxes," National Bureau of Economic Research Working Paper \$167, (July 1983).

Mascaro, Angelo, and Allan H. Meltzer. "Long" and Shon-Term Interest Rates in a Risky World," Joumal of Monetary Economics (November 1983), pp. 485-518.

Sandmo, Agnar. "On the Theory of the Competitive Firm Under Price Uncertainty," American Economic Review (March 1971), pp. $65-73$.

Tatom, John A. "Interest Rate Variability and Output, Further Evidence, "Federal Reserve Bank of St. Louis Working Paper \#84016 (July 1984a)

"A Review of the Performance of a Reduced-Form Monetarist Model," Federal Reserve Bank of St. Louis Working Paper \#84-015 (duly 1984b).

"Alternative Explanations of the 1982-83 Decline in Vefocity, in Monetary Targeting and Velocity (Federal Reserve Bank of San Francisco, 1983), pp. 22-56.

"Recent Financial Innovations: Have They Distorted the Meaning of M1?" this Review (May 1982), pp. 23-35

"Energy Prices and Short"Run Economic Pertormance," this Review (January 1981), pp. 3-17.

"Does the Stage of the Business Cycle Affect the intla

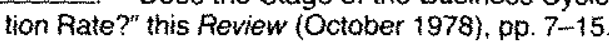

Thornton, Daniel L. "The FOMC in 1982; Deemphasizing M1," thi Review (June/July 1983), pp. 26-35.

Walfich, Henry C. "Recent Techniques of Monetary Policy," Feder: Reserve Bank of Kansas City Economic Review (May 1984), p $21-31$.

Waish, Carl E. "Interest Rate Volatility and Monetary Policy," Jo nal of Money, Credit and Banking (May 1984), pp. 133-50

Weintraut, Robert. "The Impact of the Federal Reserve Syster Monetary Policies on the Nation's Economy" (Second Repo Staff Report of the Subcommittee on Domestic Monetary Polic the Committee on Banking. Finance and Urban Affairs, Houst Representatives, 96 Cong., 2 Sess.. (Government Printing Off December 1980 ). 